\title{
The TyPological Classification OF THE OLD LEBANESE CHURCHES IN KOURA, BATROUN AND BYBLOS, FROM THE 8TH CENTURY TO THE 13TH CENTURY
}

\author{
Ghassan Aziz Issa \\ Department of Architecture, Faculty of Engineering, Democritus University of Thrace - \\ Greece 67100 Xanthi, Greece.
}

(Received November 2019 - Accepted December 2019)

\begin{abstract}
Issa, A. G. (2020). The typological classification of the old Lebanese churches in Koura, Batroun and Byblos, from the 8th Century to the 13th Century. Lebanese Science Journal, 21(1), 95-118.

The influence of the ecclesiastical architecture was very obvious on the community; it was used for proselytizing purposes and to express the greatness of the church. The church became a link between believers and heaven and a small-scale representation of the universe, where the kingdom of God extends. For example, the ceiling of churches, especially the domes, symbolizes heaven, which is the throne of God. An indispensable analysis was carried out to understand the typology of churches, based on the plan and spatial composition, therefore to make them easily recognizable. This paper primarily aims to define the typological classification of the historic Lebanese churches, to monitor the different characteristics and to develop a wider understanding of these architectural features. This study relates to ecclesiastical temples from the 8th century to the 13th century in Koura, Batroun and Byblos. Most of the historic churches and monasteries of Lebanon are located in the north of Lebanon, especially in the areas of Koura, Batroun and Byblos (Jbeil), where the majority of Christian communities still reside until now. Unfortunately, there are no remaining churches before the 8th century, especially after the great earthquake that struck Lebanon in 551 AD. The Crusader period takes place from the end of the eleventh century to the end of the thirteenth century (between 1095 and 1291 AD). In the 13th century, the Fourth Crusade left behind a series of important churches that had a great impact on the architecture of Lebanon. In total, 128 temples were studied in my article; later, I will identify them and represent their typology in six tables.
\end{abstract}

Keywords: Architecture, historic churches, typology, Lebanon, twin temples, the basilica.

\section{INTRODUCTION}

The era between the 8th and the 13th century is the most important period in our historic ecclesiastical architecture. It is located in the middle ages that lasted from the 5 th to the 15 th century. At the beginning of the sixth century, a series of terrible earthquakes struck Lebanon in 494, 502, 529, 551 (it was the greatest) and 555 AD. The earthquakes 
caused large waves of tsunamis, which flooded the entire coast of Lebanon. Unfortunately as a result, most coastal cities and many important temples were destroyed. Then during the Crusader period, the Christian Churches have increased in a significant number. After the 13th century, due to the occupation of Lebanon by the army of the Mameluks and the Ottomans, the Christian community had many difficult times until the French mandate.

At the beginning, there were major influences of the Byzantine architecture on Lebanese temples and we can say that the architecture of our historic churches was part of the Byzantine school. Later, the Cistercian monks came along with the Crusaders to various areas of Lebanon and founded many monasteries and churches. They began to build their big churches with new ideas and new typological designs. The influence was very obvious on the local architecture, so the Lebanese people acquired a new architectural and structural school; consequently, many topological changes were made to the existing local simple architecture.

Basically, The Lebanese historic church consists of two basic architectural parts:

The main nave for the laity, where the people stand during the liturgy to pray, it is the largest place in the church.

The Bema or the Sanctuary for the clergy, it is a raised platform in the eastern end, within this holy area there is the altar table.

The Sanctuary is separated from the main nave by an iconostasis, literally a wall of icons, with three or two doors, the central door (royal door) and the two doors to the right and left (deacons' doors). Also many times, porches, narthexes and outer-narthexes on the west side can be found. Generally, it is supposed that the width of the historic churches is about $1 / 3$ of the length, but in Lebanon it is often about $1 / 2$.

\section{Functional perception}

In Rome, the early Christians had been subjected to severe persecution and martyrdom. For this reason, their first gatherings were in catacombs, networks burial chamber and funeral ceremonies sites, then the Christians gathered in private homes to participate in Eucharist as a memory of Christ's sacrifice. They also gathered at the martyrdom places, at the entrance to catacombs, where Christians were buried, and above the tombs of the martyrs on the anniversary of their deaths to commemorate and to honor their memory.

After the triumph of the church, the worship of Holy Relics of Martyrs imposed the insert them inside the temples, usually under the altar table in a cavity or a small cubicle or a simple box, believing that the Holy Relics bear Divine Grace to the world.

The architecture of the Christian Orthodox Church was created concerning worship and function:

The worship was formed to honor the Martyrs of faith, where painting and architecture play a key role. This tendency expressed the deep faith of the Christians that the dead are not separated from the alive, believing that those are sleeping, therefore the cemetery is called «kimitirio» (Place of sleep in the Greek language). 
The functional significance was directly related to the architectural layout, where the Orthodox function includes two main sections:

The first half of the liturgy is the liturgy of the word, where the deacon transfers the Gospel from the altar table to the central naos (nave) and back again to the altar table, through the central door of the iconostasis.

The second half of the liturgy is Eucharist (Divine Thanksgiving), where the paten and the chalice are transferred from the Prothesis to the main nave via the iconostasis and then to the altar table.

\section{The basic rectangular plan: the Basilica}

As the Roman Empire adopted Christianity, the major church buildings were typically constructed with the basic rectangular plan, with the main nave and side aisles, and usually a raised platform at the opposite end from the door. For a long time, this type remained the most common architectural style and it is known as the Basilica Church. The Christian basilica is an elongated building with a central longitudinal axis and can be divided internally into many side aisles; the middle central nave was the most spacious; although some believe that only the multi-naved church is Basilican.

It is the oldest type of Church, which derived from the ancient Greeks, was taken over by the Romans and ended up with the Christians. It is dictated by functional reason, the need to accommodate a large number of believers in front of the Holy Bema.

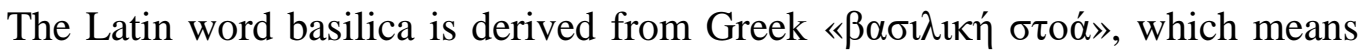
Royal Stoa; the Christians took the word from the Greeks because in these churches the King (o $\left.\beta \alpha \sigma \imath \lambda \imath \alpha^{\prime}\right)$ Christ is worshiped. Here, I would like to note that the Greek letter 'B' corresponds to the Latin letter ' $\mathrm{V}$ ', so the correct Latin word is closer to 'Vasilica' and not to 'Basilica'. The word nave is used because the shape of the barrel vaulted ceiling is related to the shape of the ship.

In Lebanon, the Christian Churches adopted the same basic plan, which was the most widely used in Lebanon. Also, the churches of the Crusaders were usually basilican; but unlike the local churches, they were in large dimensions.

The different types of plans in the historic churches of Lebanon

The primary objective of this study, as stated before, is to make a typological classification of the historic churches constructed from the 8th Century to the 13th century that has been done based upon the plan and spatial composition.

The type of worship buildings that prevailed in the local religious typology is the small simple elongated single-naved with low barrel vaulted ceiling and entrance on the west narrow side. I would like to mention that circular and polygonal buildings, which are around a geometric center and the basilicas with a transept, which is a transverse part that created to separate the main nave from the choir and to cross the plan, were not used at all in Lebanon. 
The different types of plans in the historic churches of Lebanon, which are defined by the plan, are listed as follows:

* The single-naved churches with a rectangular plan, it is the most commonly used type in Lebanon (Batroun-Kfar Hilda-Our Lady of Al Kharayeb); it is shown in figure 1.

* The single-naved churches with a square plan (Byblos - Barbara al-St. Sergius); it is shown in figure 1 .

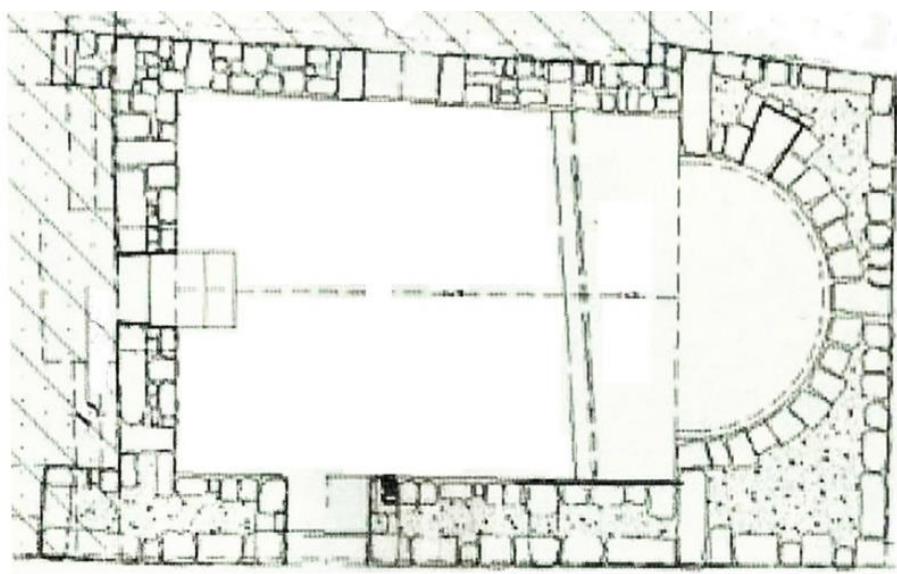

Kfar Hilda-Our Lady of Al Kharayeb

Single-naved church with rectangular plan

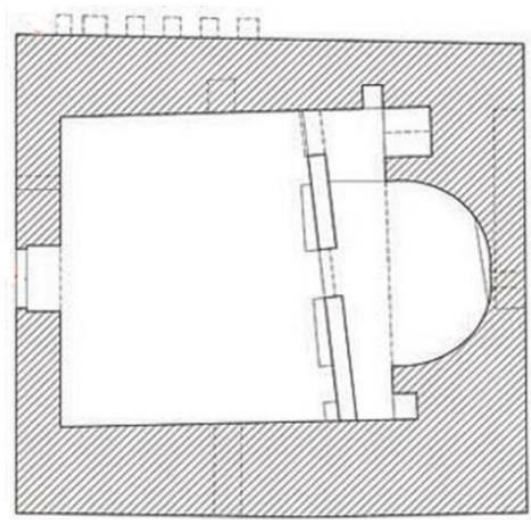

Berbara al-St Sergius Single-naved church with square plan

Figure 1. Rectangular \& square single-naved churches.

* The single-naved domed church with a square plan, where the hemispherical dome is located over a cylindrical drum. It acquires great importance because there is only one church with a dome (Byblos - Jbeil Town - St. Simon Stylites); it is shown in figure 2 .

* The single-naved church with an L-shaped plan, it is only one church (Koura - Kousba-Our Lady of Hamatoura); it is shown in figure 2.

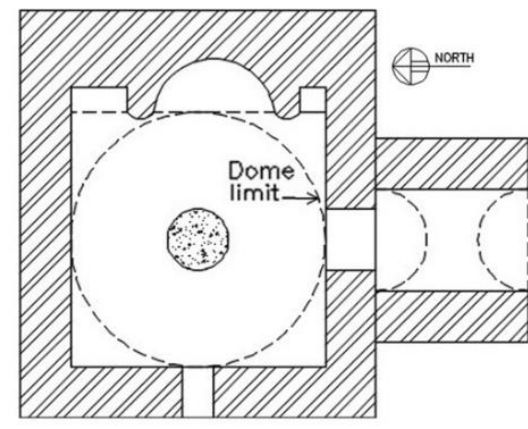

Jbeil Town-St. Simon Stylites Single-naved domed church with square plan

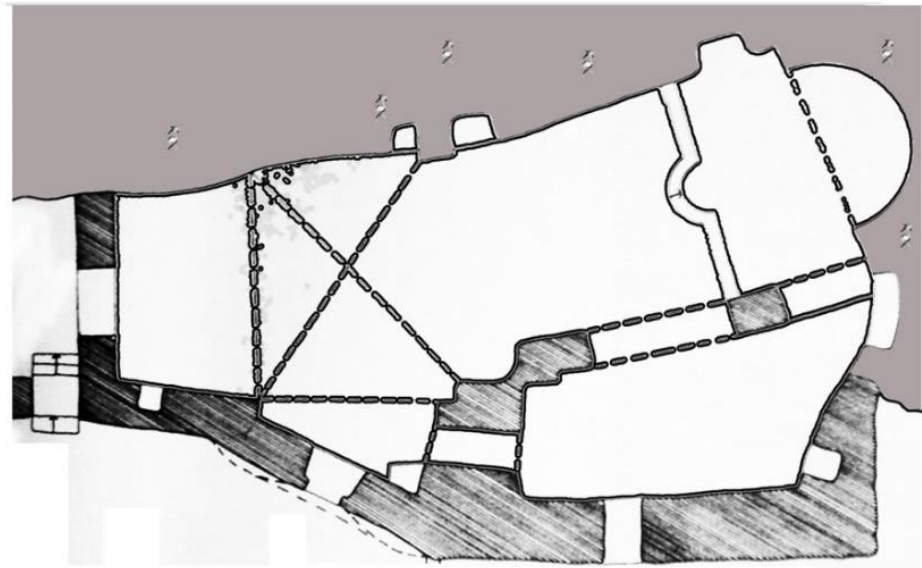

Kousba-Our Lady of Hamatoura Single-naved church with L-shaped plan

Figure 2. Domed \& L-shaped single-naved churches. 
* The triple-naved churches with a rectangular plan. The columns separate the side aisles from the main nave by arched or rectangular openings (Byblos - Jbeil Town-St. John Marcus); it is shown in figure 3.

* The triple-naved churches with a square plan. The columns separate the side aisles from the main nave by arched or rectangular openings (Koura - Amioun-St. Phocas); it is shown in figure 3.
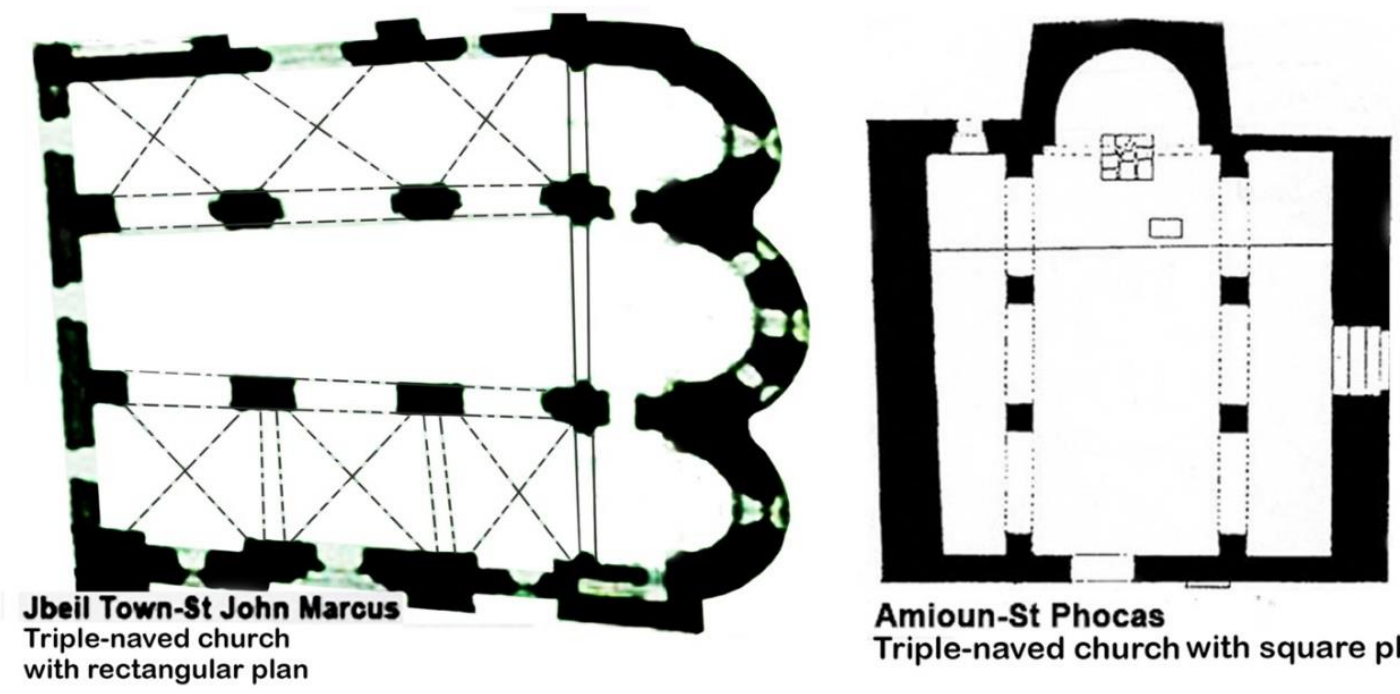

Amioun-St Phocas

Triple-naved church with square plan

Figure 3. Rectangular \& square triple-naved churches.

* The triple-naved church with a cruciform plan. The interior covering system is also visible from outside as a cruciform roof. The columns are connected with one another and with the side walls by means of arches in both directions. A high barrel vaulted ceiling above the middle main nave with two low groin vaulted ceiling above the two parallel aisles and a low groin vaulted ceiling above the western narthex make together a flat cross-shaped roof, it is only one church (Koura - Kaftoun-St. Sergius \& St. Bacchus); it is shown in figure 4.

* There is a brilliant type of a triple-naved church with a cross-in-square plan but without a dome, where the sanctuary area is added to the square shape. The volume is divided by six pillars into nine cells or compartments. The pillars are connected by the arches bearing the vaults. It is important to note the replacement of the cupolas by a groin vault ceiling, where two semicircular barrel vaults of the same diameter intersect one another; their intersection is a groin vault. Three semicircular apses inscribed within the flat east wall. The shape of the cross is inscribed on both the plan and the roof of the temple. In the past, this architectural type was the representative Byzantine style and dominated the Byzantine Church building throughout the empire (Koura - Kfar Aaqa-St. George); it is shown in figure 4. I must note here that all the triple-naved temples were built during the Crusader period. 


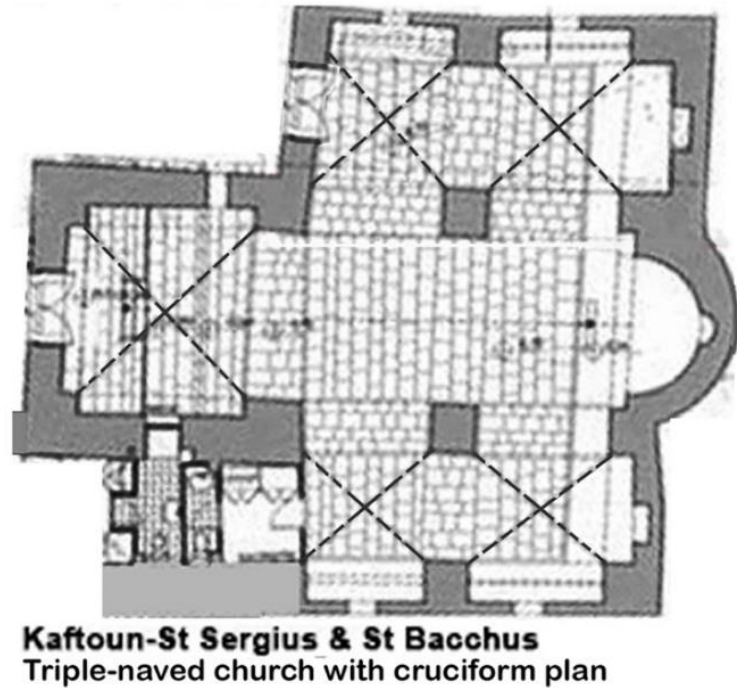

Figure 4. Cruciform \& cross-in-square triple-naved churches.

We have some types where a second church was built by the Crusaders or by the local residents in contact with another earlier existing church for three main reasons:

The need for second place to represent two liturgies, for example the Catholic liturgy and the Orthodox.

The need for expansion, another chapel was added in contact with the original for economic reasons.

$>\quad$ Sometimes the Crusaders created a new chapel next to the earliest to bury a prominent person or a member of the clergy as an indication of honor.

These churches are two types:

* The double-naved churches that were built at different times. The two naves communicate with each other through later openings in the common wall and they are accessed via two west doors. This type is two different parallel chapels, which are built in contact with each other as one church. Studied churches fall in this category are two in Lebanon:

- Koura - Enfeh - St. Simon \& Archangel Michael; it is shown in figure 5.

- Batroun - Tannourine Tahta - Our Lady \& St. Anthony; it is shown in figure 5.

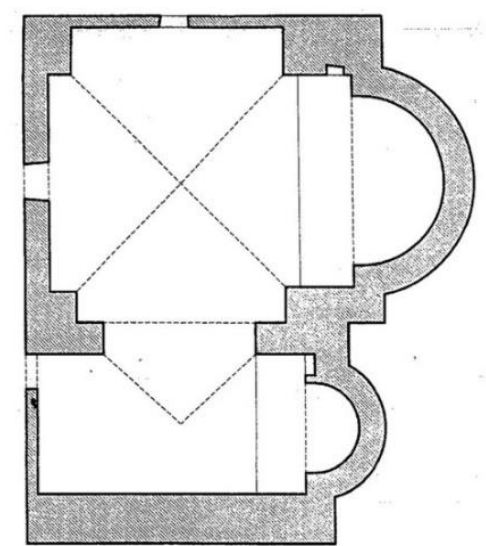

Enfeh-St Simon \& Archangel Michael

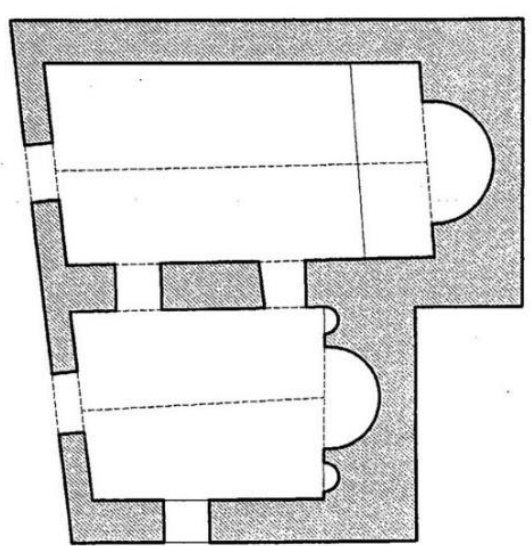

Tannourine Tahta-Our Lady\& St Anthony

Figure 5. Double-naved churches that were built at different times. 
* The churches, which were built at different times, are located in contact behind other churches. The two churches communicate with each other through later openings on the common east wall of the front church, so the second church is accessed via the west door. These are two different churches, which are built in contact with each other as one church. There are two such examples in Lebanon:

-Byblos-Bahdidat-St. Nicholas \& Our Lady of Bzez (breast); it is shown in figure 6.

-Batroun - Rachkida-St. Korkis (St. George); it is shown in figure 6.
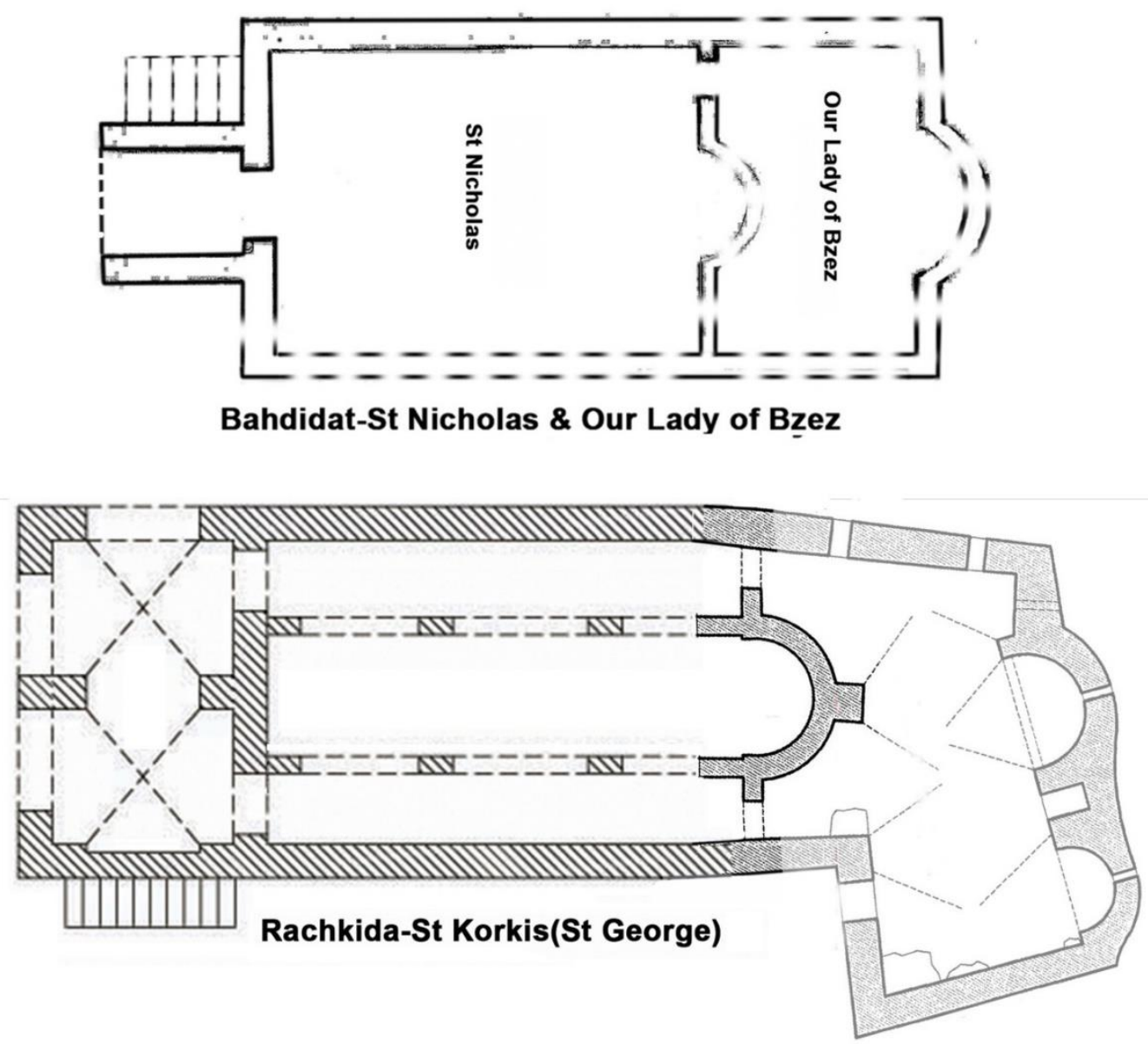

Figure 6. Churches are located in contact behind other churches.

We also have double-naved churches, where the two naves are built together at the same time. The two naves have the same roof, which shows their simultaneous construction. These churches may be categorized into two categories:

\section{The first category: The twin temples}

Another type is called the twin church. It is a very distinctive type of the Byzantine era in Lebanon, Syria, Cappadocia, Greece, Cyprus, Armenia, Balkans and North Africa. It may be sufficiently unknown in distant countries, which are outside of Byzantine culture. These temples are presented with two parallel rectangular naves, which were built together at the same time; each has its apse and its altar table, therefore it is dedicated to two different Saints. The two naves are connected by a common middle wall, which has 
rectangular openings or arches, or by one column placed in the middle. The access is done by a separate door in every nave, usually from the west, which is a principal indicator of the functional autonomy of each, but not the equivalence. The southern nave is usually the main one and gives its name to the monastery or location while the northern nave is the secondary one and it is usually the smallest. The similar face features the façade of the twin church.

However, we cannot be sure of their original use. The reason remains mysterious because of the lack of convincing data and the absence of written documents, knowing that the most were built during the Crusader period and belong to mixed architecture, as we shall see later.

This type is not local; it is a Lebanese copy of a Byzantine original. In my opinion, it did not serve the same religious necessity and the same function in all temples, so there were different purposes for their construction, depending on the area and the time. We have many theories about the function of the twin churches; I would like to point out some thoughts:

The early Christians used the same buildings to bury their martyrs and to perform their worship together, so these churches were places of worship and burial together for the performance of the Divine Liturgy. From the 4th century, the Christians began to bury the bodies of the martyrs in the churches and later they began to bury their priests. So they had a funerary and a martyrological function (worship of the martyr). These functions were passed on tradition; where we see that one of the two naves was built for funerary function usually the northern one. The frescoes, the presence of a large number of crosses and the tombs of the honored clergy, which can be found in the church, emphasize this concept (Koura -Bkeftine-Our Lady of the Dormition \& St. George).

During the Crusader period, sometimes the Crusaders built a twin church to bury the donor or any member of his family in one of the two naves (Batroun Tannourine Fawqa (upper) - St. Challita \& St. George) or they used one of the two existing naves to bury their dead, so they created a new function here, which is the funerary function (Koura - Kousba-St. Dimitrios \& St. Nicholas).

They were used in the need to represent two liturgies of two doctrines, e.g. Orthodox and Catholic, where two languages may have been used.

Another reason for some churches is that the temple was built in order to honor concurrent both Saints, especially the Virgin Mary, since most of these churches are dedicated also to the Virgin, to express their great appreciation and the need to protect them together with the local Saint, as shown in the tables of the historic churches (Batroun - Douma - St. John \& Our Lady of the Nativity).

It is known that according to the Greek Church tradition, the women sit on the left side (north) and the men on the right side (south). Also, in the twin temples, the south nave is the main one while the north nave is the secondary one; according to the above reference, we can conclude that the main south nave is for men on the right and the north is for women on the Left.

The twin temples will be specified in the next paragraph, in relation to the construction period, the existence within monasteries, morphology and if they have graves. 
$\underline{\text { In koura }}$

- Bkeftine - Our Lady of the Dormition \& St. George

(Crusader period / Mixed-character architecture / It has a grave / Located in the monastery of Our Lady of Dormition).

- Kousba-St. Dimitrios \& St. Nicholas

Initially, there were two western doors, one door for each one, but later a new monastery building was attached to the west wall and now has only one new north door. (Crusader period / Mixed-character architecture / It has a grave / Located in the monastery St. Dimitrios).

- Deddeh-St. Anthony; it is shown in figure 7.

It has a northern and southern door. (Crusader period / Mixed-character architecture / It has a circular pillar in the middle).

Note that:

- These three churches are dated to the Crusader period.

- Two churches are located in monasteries.

- Two churches of three have graves. They are dated to the Crusader period, located in monasteries and they belong to mixed-character architecture.

\section{$\underline{\text { In Batroun }}$}

- Douma-St. John the Baptist \& Our Lady of the Nativity

(Around the $8^{\text {th }}$ century / Local architecture / It has a grave / Located in the monastery St. John).

- Hardine-St. George \& St. Edna; it is shown in figure 7.

(Around the $8^{\text {th }}$ century / Local architecture).

- Sghar-St. Sophia \& St. Stephen

It has a northern and western door. (Crusader period / Mixed-character architecture / It has a grave).

- Smar Jbeil-Sts Basilios \& Nohra

(Crusader period / Architecture of the Crusaders).

7.

- Tannourine Fawqa (upper)-St. Challita \& St. George; it is shown in figure

(Crusader period / Mixed-character architecture / It has a grave / It has a rectangular column in the middle).

Note that:

- Three churches are dated to the Crusader period.

- Only one church is located in a monastery.

- Three churches of five have graves, where two churches are dated to the Crusader period, one is located in a monastery and two belong to mixed-character architecture.

In Byblos

- Chamat-St. Thecla \& St. Stephen; it is shown in figure 7.

(Crusader period / Mixed-character architecture / It has a grave / It has two circular pillars in the middle)

- Dmalsa-St. Nohra \& St. Sophia

(Crusader period / Mixed-character architecture / It has a rectangular column in the middle) 
Note that:

- These two churches are dated to the Crusader period.

- No one is located in a monastery.

- One church of two has a grave.

According to the above data, most of the twin churches have tombs, assuming that the churches may have been used for funerary function.
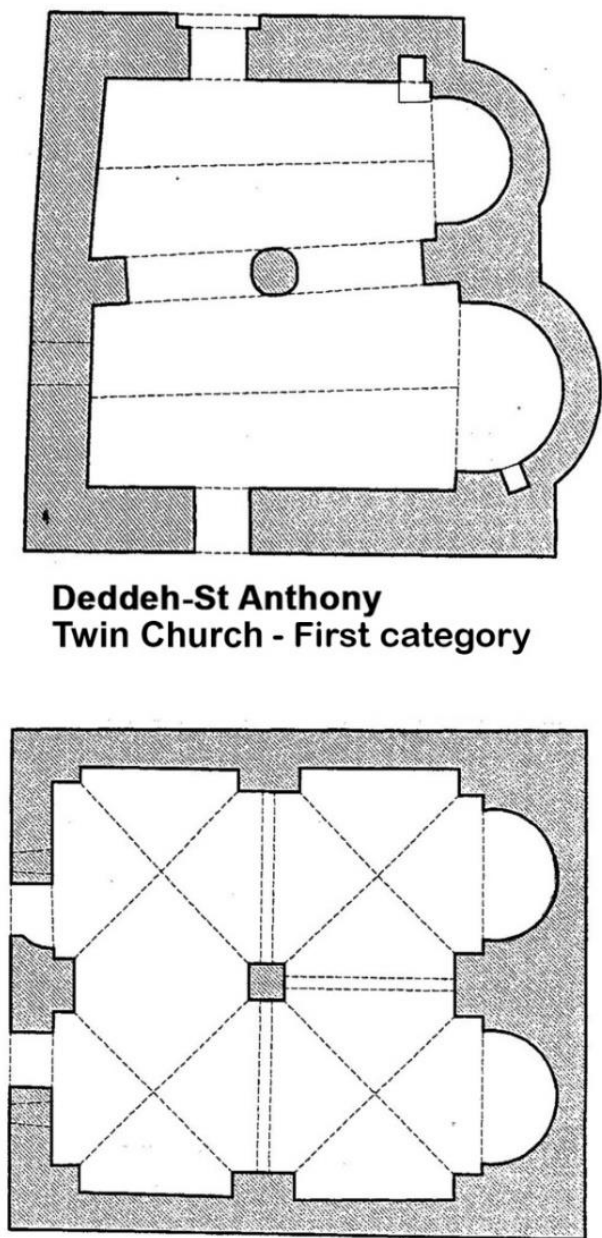

Tannourine Fawqa -St Chalita \& St George Twin Church - First category

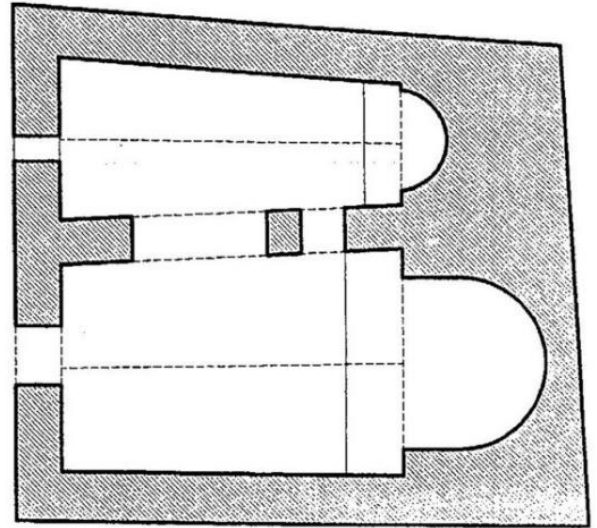

Hardine-St George \& St Edna Twin Church - First category

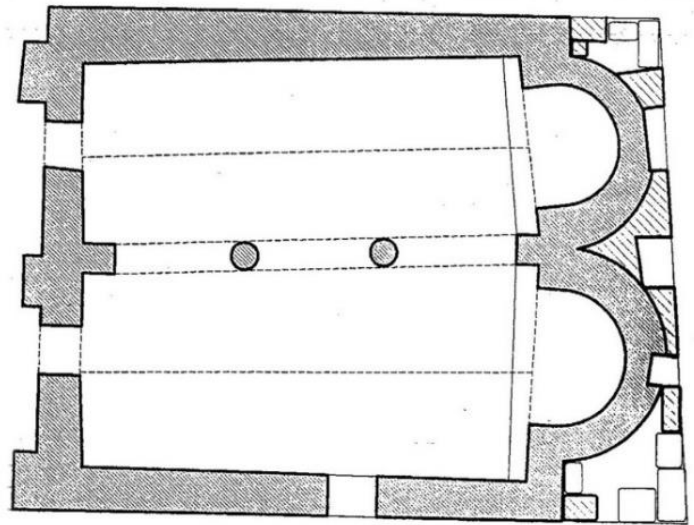

Chamat-St Thecla \& St Estephan Twin Church - First category

Figure 7. Different types of twin churches.

\section{The second category - The double-naved temples}

The second category consists of two types, they are:

* The double-naved churches, which look like the twin temples, but they are accessed by a single western door. Therefore it is a double-naved temple with two parallel rectangular spaces, which were built together at the same time; the two spaces are connected by rectangular openings or arches. It is dedicated to two different Saints; each one has its apse and its altar table, now the two naves are used for the same dogma. Studied churches fall in this category are: 
- Batroun - Bqosmaya -Our Lady of Bzez \& St. Simon (Crusader Period); it is shown in figure 8.

- Batroun - Rachkida-St. Korkis - the second church (Crusader Period).

- Byblos - Edde-the Archangels Michael \& Gabriel (About the 11th century); it is shown in figure 8.

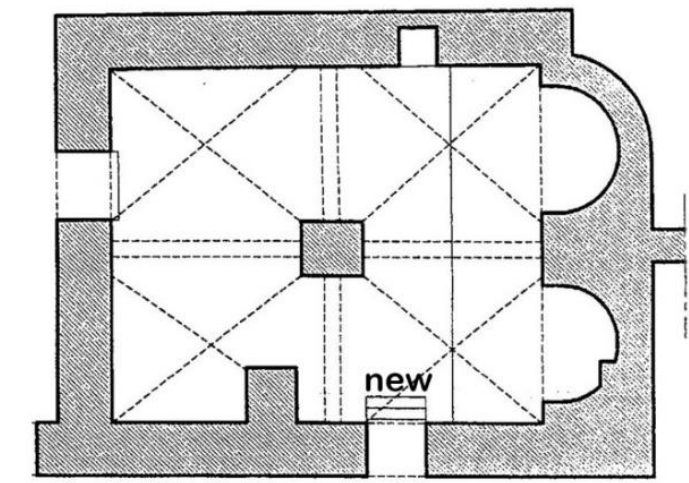

Bqosmaya-Our Lady of Bzez \& St Simon Double-naved church - Second category

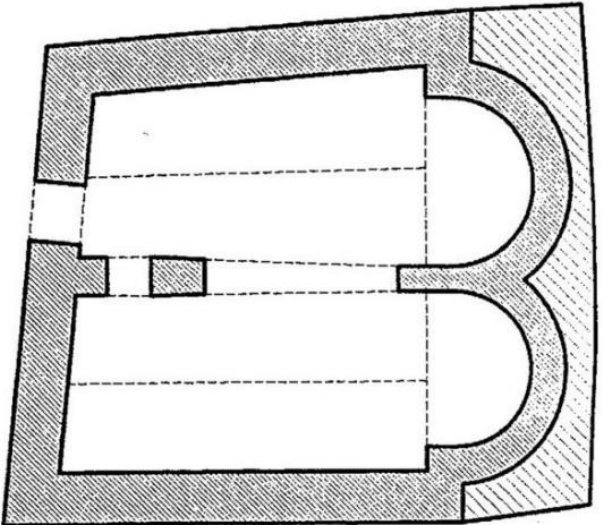

Edde-the Archangels Michael \& Gabriel Double-naved church - Second category

Figure 8. Double-naved churches that are accessed by a single western door.

* Finally, there are two double-naved churches with two parallel rectangular spaces, which were built together at the same time and the access is done via two western doors, but the two spaces are not connected. They are dedicated to two different Saints; each one has its apse and its altar table:

-Byblos - Edde - St. Theodoros \& St. John (In bad condition - Crusader Period).

-Byblos - Ain Kfaa-St. Simon and St. Abdas (In bad condition - Crusader Period); it is shown in figure 9 .

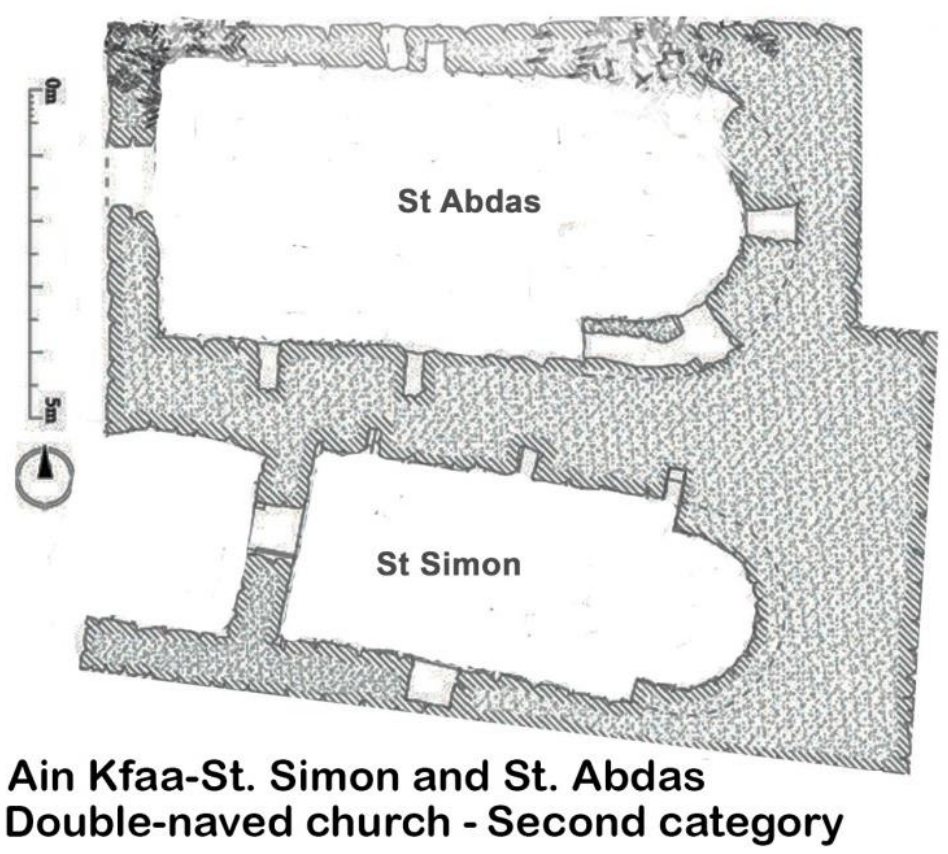

Figure 9. Double-naved church that is not connected. 
Notes about the churches of the second category:

- The churches are dated to the Crusader period.

- No one is located in a monastery.

- No one has a grave.

Generally, the vast majority of double-naved churches were built during the Crusader period with two exceptions only in Batroun: Hardine-St. George \& St. Edna and Douma-St. John the Baptist \& Our Lady of the Nativity, which meet the requirements of the twin temples.

\section{The different types of plans that have graves}

In this paragraph, we will talk about temples that have graves in relation to their typology. These graves are located in different parts of the churches, as follows:

- In a big hollow within the wall of the nave or the apse.

- $\quad$ In an underground passage below the church.

- $\quad$ In a courtyard, open-air space of the church.

These temples are:

Cavernous churches

- Koura - Qalamoun-St. Marina; it is shown in figure 10.

A large carved tomb is on the cave's floor.

- Batroun - Hardine - St. Challita \& St. Nohra (St. Light); it is shown in figure 10.

Some bones were discovered in the underground of the west side.

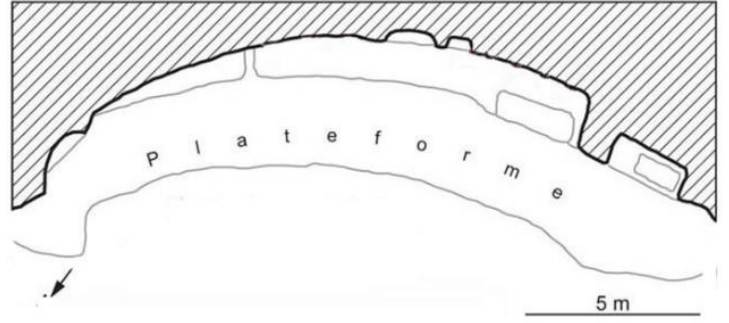

Qalamoun-St Marina-cave Cavernous church

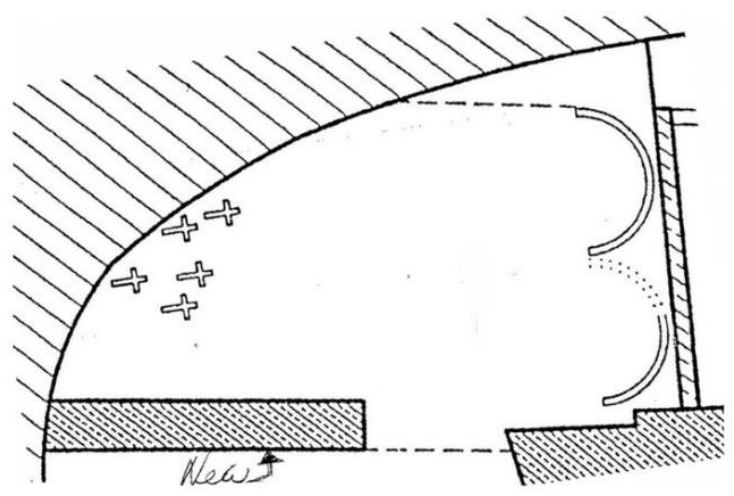

Hardine-St Chalita \& St Nohra(St Light)-cave Cavernous church

Figure 10. Cavernous churches that have graves.

The single-naved churches

- Batroun - Douma-St. Nohra (St. Light).

In the place of the Diaconicon, there is a tomb inside the wall.

- Byblos - Bahdidat-St. Nicholas \& Our Lady of Bzez; it is shown in figure 6.

An old cemetery extends to the south side of the church.

- Koura - Enfeh-Saint John the Baptist.

It was built over an old underground burial chamber, where the access is through the Sanctuary. 
- Koura - Qolhat Our Lady of Balamand; it is shown in figure 12.

Some bones were discovered near the walls on the west side of the church.

The double-naved churches

- Byblos - Chamat - St. Thecla \& St. Stephen (twin church); it is shown in figure 7.

In the Sanctuary, there is a small door that leads to a crypt below the ground, used for burial.

- Koura - Bkeftine - Our Lady of the Dormition \& St. George (twin church). the church.

In the north apse, there is a small door leading to an underground passage under

- Koura - Kousba - St. Dimitrios \& St. Nicholas (twin church).

In the apse of the northern nave (St. Nicholas), there is a door, which leads to an underground passage.

- Koura - Kfar Hazir - St. George and St. Theodoros.

A contemporaneous tomb is located outside in the courtyard.

-Batroun - Douma-St. John \& Our Lady of the Nativity (twin church).

A tomb was discovered in the underground of the northern nave.

- Batroun - Sghar - St. Sophia \& St. Stephen (twin church).

nave.

There is an epitaph with a Syrian inscription on the south wall of the southern in figure 7.

- Batroun - Tannourine Fawqa-St. Challita \& St. George (twin church); it is shown

There are old tombs in the northern nave.

It is noteworthy that all double nave churches, which have tombs, are classified in twin churches type. Almost all tombs of twin churches are located in the north nave, which is the secondary nave, although the temple Batroun - Sghar - St Sophia \& St Stephen has an epitaph on the south main nave; this leads us to the fact that usually, the main reason for the northern nave's existence was to put a tomb inside it.

The triple-naved churches

- Byblos - Maad-St. Charbel the Martyr; it is shown in figure 11.

The east chamber of the temple, which was built a little later behind the three apses, has a Crusader grave.

- Koura - Amioun-St. George Al Dahliz.

Below the church in the ground, there are underground catacombs, which are accessed from the northern nave. 


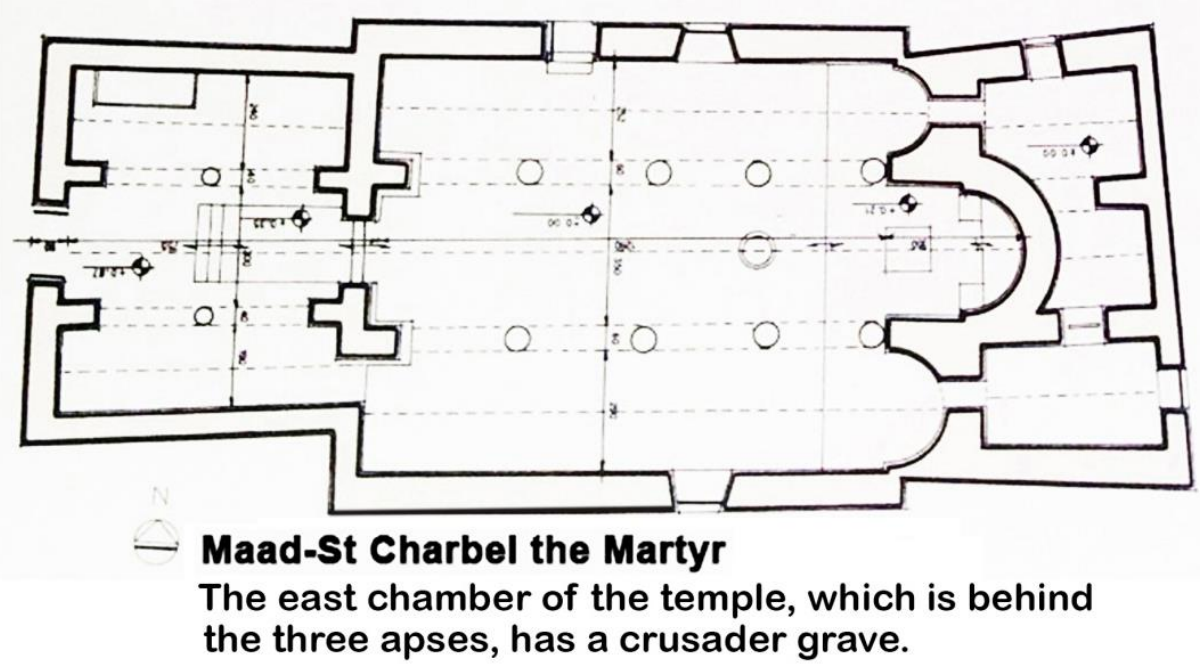

Figure 11. Triple-naved church that has a Crusader grave.

The different types of apses in the historic churches of Lebanon

Most churches are single-apsed, although we can see many double-apsed and triple-apsed churches, which are located side by side to the same east side. In our historic churches, there are no apses on different sides. The term "Triconch", which means "three shells" in the Greek language, is used to identify the triple-apsed church on three sides of a square. This eastern Byzantine type of apses was used to inscribe a Greek cross in the church. Often, the apses are covered by a quarter dome.

The types of churches' apses are:

* Single-apsed churches, one flat apse in a single-naved temple. This type is found frequently in churches of Byblos and is dated to the Crusader period (Byblos Hakel-Our Lady of Hakel and Bshalli- St. George).

* Single-apsed church, one flat apse in a triple-naved temple. There is only one church (Byblos - Blat al-St. Elias); it is shown in figure 12.

* Single-apsed churches, one semicircular apse in a single-naved temple. This type is the most widely used in Lebanon (Koura - Qolhat-Our Lady of Balamand); it is shown in figure 12 .

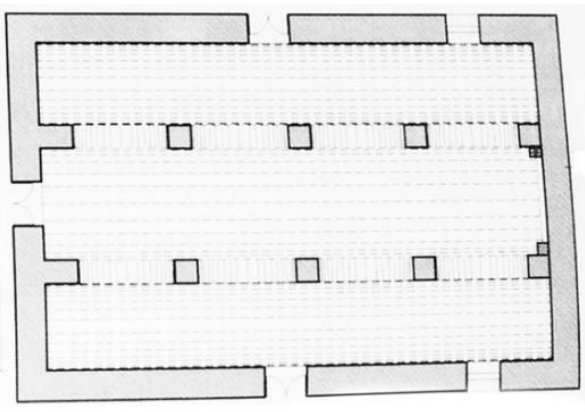

Blat al-St Elias

Single-apsed church, one flat apse in a triple-naved temple

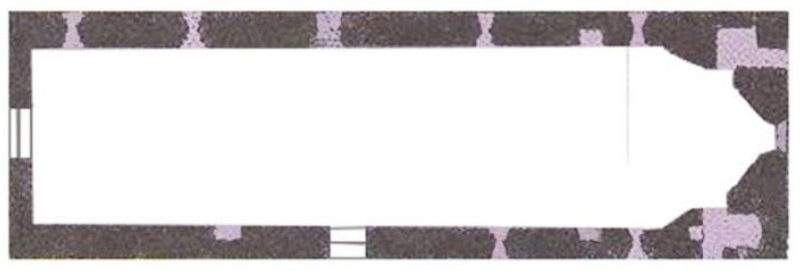

Qolhat-Our Lady of Balamand Single-apsed churches, one semicircular apse in a single-naved temple

Figure 12. Flat \& semicircular single-apsed churches. 
* Double-apsed churches, two semicircular apses in a double-naved temple (Byblos - Chamat-St. Thecla \& St. Stephen).

* Double-apsed churches - Biconch, two semicircular apses in a singlenaved temple, these churches are:

-Koura - Kfar Hazir - St. George and St. Theodoros.

-Batroun - Hardine - St. Challita \& St. Nohra.

(It is a cavernous temple, where two semicircular apses are located in the cave).

-Batroun - Hardine - St Estephan (Stephen); it is shown in figure 13. rock).

(It is a stone carved temple, where two semicircular apses were carved into the

-Batroun - Hardine - St Phocas \& St. George; it is shown in figure 13.

-Batroun - Rachkida - St. Korkis - The second church.

-Byblos - Amchit - Kfarsala - St. John the Baptist.

-Byblos - Habil - Our Lady of Habil.

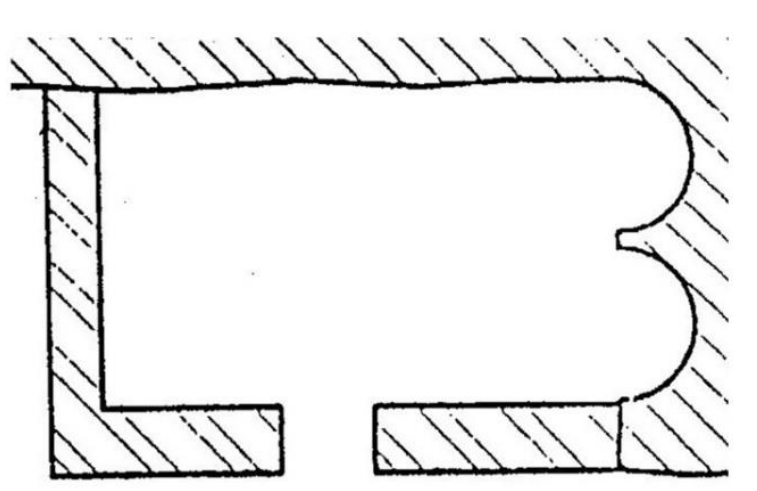

Hardine-St Estephan-carved cave Biconch Church

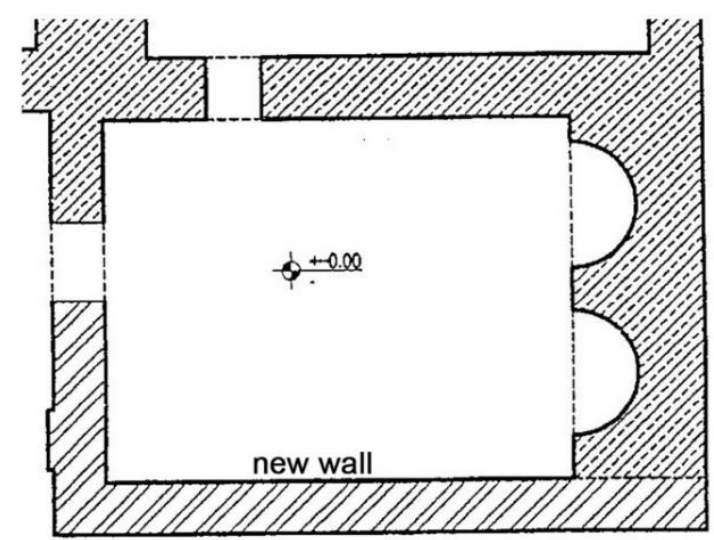

Hardine-St Phocas \& St George Biconch Church

Figure 13. Double-apsed churches (Biconch).

I think that the double-apsed church has been used in the need to honor two Saints simultaneously and to represent two doctrines, e.g. the Orthodox and Catholic. Generally, the single apse and double apse type take the following forms:

figure 14.

Carved into the natural rock (Byblos - Barbara al-St John); it is shown in

Inscribed within the flat east wall (Byblos - Chikhane-St Thecla); it is shown in figure 14. 


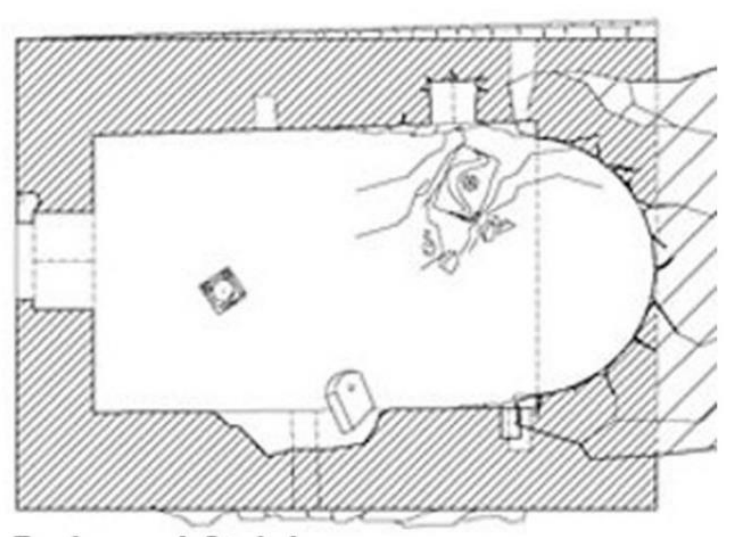

Berbara al-St John

Single apse is carved into the natural rock

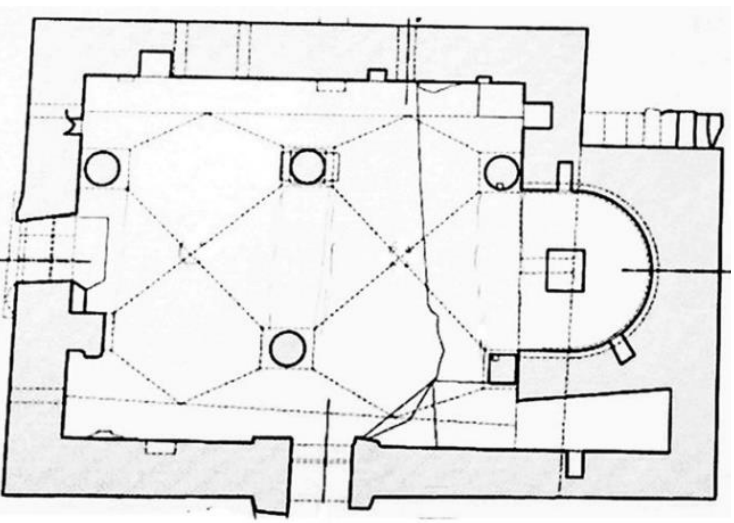

Chikhane-St Thecla

Single apse is inscribed within the flat east wall

Figure 14. Inscribed apses within the eastern side.

- Protruding from the eastern wall outwards, as follows:

- Semicircular shape (Batroun - Edde-St Sava); it is shown in figure 15.

- Rectangular shape (Koura - Kousba-St Barbara); it is shown in figure 15.

- Polygonal shape (Batroun - Abrine-kfarkhollos-St. Sassine).

Knowing that there is also a construction reason to make it inscribed within the wall, which is to further strengthen the construction.

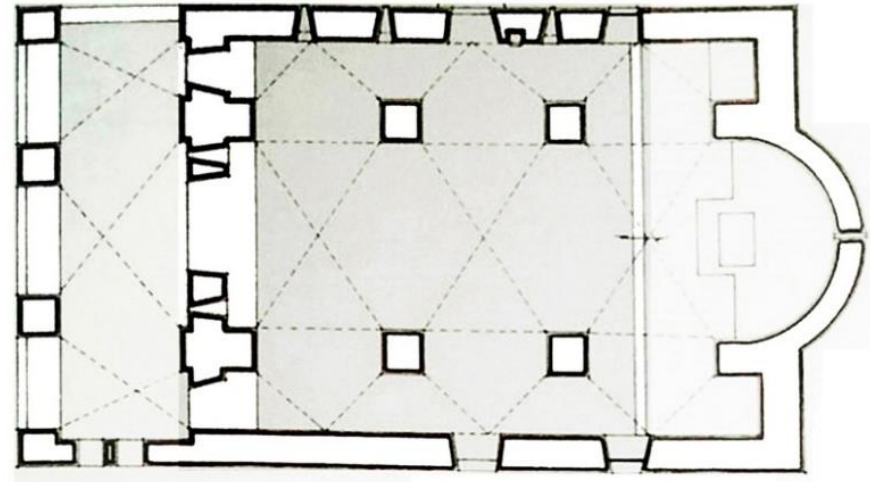

Edde-St Sava

Single apse is protruding from the eastern wall in a Semicircular shape

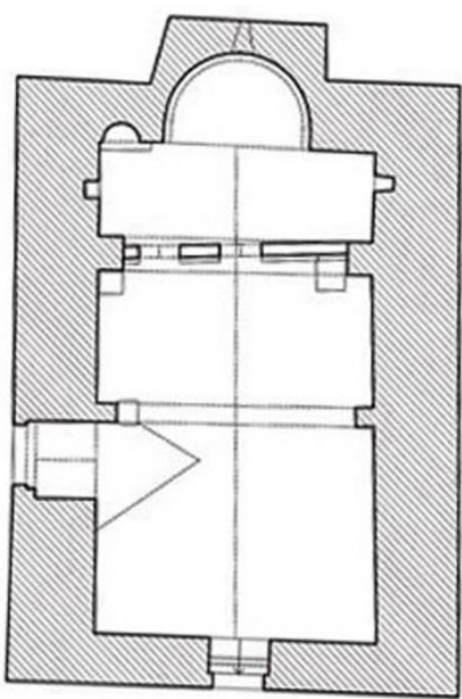

Kousba-St Barbara

Single apse is protruding from the eastern wall in a Rectangular shape

Figure 15. Protruding apses from the eastern wall.

* Triple-apsed churches, three semicircular apses in a triple-naved temple (Koura - Kfar Aaqa-St. George, Byblos - Jbeil Town-St John Marcus and Byblos - MaadSt Charbel the Martyr); they are shown in figure 3, 4 \& 11 . The triple-apsed church, which was developed in relation to the Byzantine architecture, is a major change of the 
Sanctuary and an important tripartite form in the east, two secondary apses with the central one. This change was created for functional reasons, the northern apse on the left is the Prothesis, where the Liturgy of preparation takes place, and the southern apse on the right is the Diaconicon, where the sacred objects, the vestments, books, etc. are stored. Also, we see another use where every apse of the temple has its altar table and it is dedicated to a different Saint (Byblos - Maad - St. Charbel the Martyr); it is shown in figure 11 .

The triple apse type exists only in triple-naved churches and these apses can take different forms:

- $\quad$ They can be protruding from the east wall in a semicircular shape (Byblos - Jbeil Town-St. John Marcus); it is shown in figure 3.

- $\quad$ They can be inscribed within the flat east wall (Koura - Kfar Aaqa-St. George); it is shown in figure 4.

- $\quad$ The two side apses can be inscribed within the flat east wall and the central apse protrudes outward in a semicircular shape (Byblos - Maad - St. Charbel the Martyr); it is shown in figure 11 .

Tables of historic churches grouped by regions and observations

The total number of churches, which I have examined, is 128 churches. The monuments have been selected representing all the types that existed in the selected regions during the required period:

- 36 churches in Koura; they are shown in table 1.

- 33 churches in Batroun; they are shown in table 2.

- 59 churches in the Byblos; they are shown in table 3.

I will consider that the following four churches:

1- Koura - Enfeh - St. Simon \& Archangel Michael

2- Batroun - Rachkida-St. Korkis (St. George)

3- Batroun - Tannourine Tahta (lower) - Our Lady \& St. Anthony

4- Byblos - Bahdidat - St. Nicholas \& Our Lady of Bzez (breast) as being eight, because each one of them is composed of two independent churches, which are built at different times. It is observed that later connection openings were created within these churches.

The purpose of this paragraph is to conjure up the classification of church architecture on the base of the typological characteristics; the basic typological features are the plan and the spatial composition. Therefore, the following tables will show and describe the typologies' categories of plans and apses in the historic churches of Lebanon. 
Table 1. Typology of the historic churches in Koura.

\begin{tabular}{|c|c|c|c|c|c|c|c|}
\hline $\mathbf{N}^{\mathbf{0}}$ & Region - Name of the Church & $\begin{array}{l}\text { Single } \\
\text { Nave } \\
\end{array}$ & $\begin{array}{l}\text { Double } \\
\text { Nave }\end{array}$ & $\begin{array}{l}\text { Triple } \\
\text { Nave } \\
\end{array}$ & $\begin{array}{l}\text { Single } \\
\text { Apse } \\
\end{array}$ & $\begin{array}{l}\text { Double } \\
\text { Apse }\end{array}$ & $\begin{array}{l}\text { Triple } \\
\text { Apse }\end{array}$ \\
\hline 1. & Ain Ikreen -St. Edna & $\bullet$ & & & $\bullet$ & & \\
\hline 2. & Amioun-St. George AI Dahliz & & & $\bullet \square$ & $\bullet$ & & \\
\hline 3. & Amioun-St. Phocas & & & $\bullet \square$ & $\bullet$ & & \\
\hline 4. & Barghoun-St. Barbara & $\bullet$ & & & $\bullet$ & & \\
\hline 5. & $\begin{array}{l}\text { Bhabboosh- Our Lady } \\
\text { of Al Rass }\end{array}$ & $\bullet$ & & & $\bullet$ & & \\
\hline 6. & $\begin{array}{l}\text { Bkeftine-Our Lady of the } \\
\text { Dormition \& St. George }\end{array}$ & & $\bullet \|$ & & & $\bullet$ & \\
\hline 7. & Bkeftine-St. Elias the River & $\bullet$ & & & $\bullet$ & & \\
\hline 8. & $\begin{array}{l}\text { Bsarma- Our Lady } \\
\text { of the Wilderness }\end{array}$ & $\bullet$ & & & $\bullet$ & & \\
\hline 9. & Btaaboura-St. Romanos & $\bullet$ & & & $\bullet$ & & \\
\hline 10. & Bziza-Our Lady of the River & $\bullet$ & & & $\bullet$ & & \\
\hline 11. & Bziza-St. Elias & & $\bullet$ & & & $\bullet$ & \\
\hline 12. & $\begin{array}{l}\text { Dar Bishtar- Our Lady } \\
\text { of Dar Bishtar }\end{array}$ & $\bullet$ & & & $\bullet$ & & \\
\hline 13. & Deddeh-St. Anthony & & $\bullet \|$ & & & $\bullet$ & \\
\hline 14. & $\begin{array}{l}\text { Enfeh-Our Lady of the } \\
\text { Natour }\end{array}$ & $\bullet$ & & & $\bullet$ & & \\
\hline 15. & Enfeh-Our Lady of the Wind & $\bullet$ & & & $\bullet$ & & \\
\hline 16. & Enfeh-Saint John the Baptist & $\bullet$ & & & $\bullet$ & & \\
\hline 17. & Enfeh-St. Catherine & $\bullet$ & & & $\bullet$ & & \\
\hline $\begin{array}{l}18 \\
\alpha \\
\end{array}$ & $\begin{array}{l}\text { Enfeh - St. Simon } \\
\text { \& Arch. Michael } \\
\end{array}$ & $\bullet$ & & & $\bullet$ & & \\
\hline $\begin{array}{l}18 \\
\beta\end{array}$ & $\begin{array}{l}\text { Enfeh - St. Simon } \\
\text { \& Arch. Michael }\end{array}$ & $\bullet$ & & & $\bullet$ & & \\
\hline 19. & $\begin{array}{l}\text { Ijd Ibreen-Our Lady } \\
\text { of Marghala }\end{array}$ & $\bullet$ & & & $\bullet$ & & \\
\hline 20. & $\begin{array}{l}\text { Kaftoun- Our Lady } \\
\text { of the Dormition }\end{array}$ & $\bullet$ & & & $\bullet$ & & \\
\hline 21. & $\begin{array}{l}\text { Kaftoun-St Sergius } \\
\text { \& St. Bacchus } \\
\end{array}$ & & & $\bullet$ & $\bullet$ & & \\
\hline 22. & Kfar Aaqa-St. George & & & $\bullet$ & & & $\bullet$ \\
\hline 23. & $\begin{array}{l}\text { Kfar Aaqa-St. Nohra(St. } \\
\text { Light) }\end{array}$ & $\bullet$ & & & $\bullet$ & & \\
\hline 24. & $\begin{array}{l}\text { Kfar Hazir-Our Lady } \\
\text { of the Dormition }\end{array}$ & $\bullet \square$ & & & $\bullet$ & & \\
\hline 25. & $\begin{array}{l}\text { Kfar Hazir-St. George } \\
\text { And St. Theodoros }\end{array}$ & $\bullet$ & & & & $\bullet \mathbf{L}$ & \\
\hline 26. & $\begin{array}{l}\text { Kfar Qahel-St. Elias the } \\
\text { River }\end{array}$ & $\bullet$ & & & $\bullet$ & & \\
\hline 27. & Kousba- Our Lady & $\bullet$ & & & $\bullet$ & & \\
\hline
\end{tabular}




\begin{tabular}{|l|l|l|l|l|l|l|l|}
\hline & of Hamatoura & & & & & \\
\hline$N^{\circ}$ & Region - Name of the Church & $\begin{array}{l}\text { Single } \\
\text { Nave }\end{array}$ & $\begin{array}{l}\text { Double } \\
\text { Nave }\end{array}$ & $\begin{array}{l}\text { Triple } \\
\text { Nave }\end{array}$ & $\begin{array}{l}\text { Single } \\
\text { Apse }\end{array}$ & $\begin{array}{l}\text { Double } \\
\text { Apse }\end{array}$ & $\begin{array}{l}\text { Triple } \\
\text { Apse }\end{array}$ \\
\hline 28. & $\begin{array}{l}\text { Kousba- Our Lady } \\
\text { of the Nativity }\end{array}$ & $\bullet$ & & & $\bullet$ & & \\
\hline 29. & Kousba-St. Barbara & $\bullet$ & & & $\bullet$ & & \\
\hline 30. & $\begin{array}{l}\text { Kousba-St. Dimitrios } \\
\text { \& St. Nicholas }\end{array}$ & & $\bullet \|$ & & & $\bullet$ & \\
\hline 31. & Kousba-St. Joseph & $\bullet$ & & & $\bullet$ & & \\
\hline 32. & Qalamoun-St. Marina & cavernous temple & & & \\
\hline 33. & $\begin{array}{l}\text { Qolhat-Our Lady of } \\
\text { Balamand }\end{array}$ & $\bullet$ & & & $\bullet$ & & \\
\hline 34. & Rishdibbeen-St. Domitian & $\bullet$ & & & $\bullet$ & & \\
\hline 35. & Rishdibbeen-St. Jacob & $\bullet$ & & & $\bullet$ & & \\
\hline 36. & $\begin{array}{l}\text { Zakroun-St. Sergius } \\
\text { \& St. Bacchus }\end{array}$ & $\bullet$ & & & $\bullet$ & & \\
\hline
\end{tabular}

$\square$ : Square Plan / I: Twin Church / L: Biconch Church

Table 2. Typology of the historic churches in Batroun

\begin{tabular}{|c|c|c|c|c|c|c|c|}
\hline $\mathbf{N}^{\mathbf{o}}$ & Region-Name of the Church & $\begin{array}{l}\text { Single } \\
\text { Nave } \\
\end{array}$ & $\begin{array}{l}\text { Double } \\
\text { Nave } \\
\end{array}$ & $\begin{array}{l}\text { Triple } \\
\text { Nave } \\
\end{array}$ & $\begin{array}{l}\text { Single } \\
\text { Apse }\end{array}$ & $\begin{array}{l}\text { Double } \\
\text { Apse } \\
\end{array}$ & $\begin{array}{l}\text { Triple } \\
\text { Apse }\end{array}$ \\
\hline 1. & $\begin{array}{l}\text { Abrine-kfarkhollos-St. } \\
\text { Sassine }\end{array}$ & • & & & • & & \\
\hline 2. & $\begin{array}{l}\text { Abrine-St. Charbel the } \\
\text { Martyr }\end{array}$ & $\bullet$ & & & $\bullet$ & & \\
\hline 3. & Asya-Our Lady of the Castel & $\bullet$ & & & $\bullet$ & & \\
\hline 4. & Bchaaleh-St. Domitian & $\bullet$ & & & $\bullet$ & & \\
\hline 5. & $\begin{array}{l}\text { Bqosmaya-Our Lady of } \\
\text { Bzez(breast) \& St. Simon }\end{array}$ & & $\bullet$ & & & $\bullet$ & \\
\hline 6. & Douma-St. Challita & $\begin{array}{c}\bullet \square \\
\end{array}$ & & & $\bullet$ & & \\
\hline 7. & Douma-St. Domitian & - $\square$ & & & $\bullet$ & & \\
\hline 8. & $\begin{array}{l}\text { Douma-St. John the Baptist } \\
\text { \& Our Lady of the Nativity }\end{array}$ & & $\bullet \|$ & & & $\bullet$ & \\
\hline 9. & Douma-St. Nohra (St. Light) & $\bullet$ & & & $\bullet$ & & \\
\hline 10. & Edde-St. Mammes & $\bullet$ & & & $\bullet$ & & \\
\hline 11. & Edde-St. Sava & & & $\bullet$ & $\bullet$ & & \\
\hline 12. & $\begin{array}{l}\text { Hamat- Our Lady } \\
\text { of Al Nouriyeh }\end{array}$ & $\bullet$ & & & $\bullet$ & & \\
\hline 13. & $\begin{array}{l}\text { Hardine-St. Challita } \\
\text { \& St. Nohra }\end{array}$ & \multicolumn{3}{|c|}{ cavernous temple } & & $\bullet \mathbf{L}$ & \\
\hline 14. & $\begin{array}{l}\text { Hardine-St } \\
\text { (Stephen) }\end{array}$ & $\bullet$ & $\begin{array}{l}\text { Stone } \\
\text { temple }\end{array}$ & carved & & $\bullet \mathbf{L}$ & \\
\hline 15. & $\begin{array}{l}\text { Hardine-St. George \& St. } \\
\text { Edna }\end{array}$ & & $\bullet \|$ & & & $\bullet$ & \\
\hline 16. & Hardine-St Phocas & $\bullet$ & & & & $\bullet \mathbf{L}$ & \\
\hline
\end{tabular}




\begin{tabular}{|c|c|c|c|c|c|c|c|}
\hline & \& St. George & & & & & & \\
\hline $\mathbf{N}^{\mathbf{0}}$ & Region - Name of the Church & $\begin{array}{l}\text { Single } \\
\text { Nave }\end{array}$ & $\begin{array}{l}\text { Double } \\
\text { Nave }\end{array}$ & $\begin{array}{l}\text { Triple } \\
\text { Nave }\end{array}$ & $\begin{array}{l}\text { Single } \\
\text { Apse }\end{array}$ & $\begin{array}{l}\text { Double } \\
\text { Apse }\end{array}$ & $\begin{array}{l}\text { Triple } \\
\text { Apse }\end{array}$ \\
\hline 17. & Hardine-St. Theodoros & $\bullet$ & & & $\bullet$ & & \\
\hline 18. & $\begin{array}{l}\text { Kfar Chleymane-Our } \\
\text { Lady of Naya }\end{array}$ & \multicolumn{6}{|c|}{ cavernous temple } \\
\hline 19. & $\begin{array}{l}\text { Kfar Hay-Our Lady of Kfar } \\
\text { Hay or Najat (Deliverance). }\end{array}$ & $\bullet$ & & & $\bullet$ & & \\
\hline 20. & Kfar Hay-St. Sava & $\bullet$ & & & $\bullet$ & & \\
\hline 21. & $\begin{array}{l}\text { Kfar Hilda- Our Lady } \\
\text { of Al Kharayeb }\end{array}$ & $\bullet$ & & & $\bullet$ & & \\
\hline 22. & Kfar Hilda-St. Peter & $\bullet$ & & & $\bullet$ & & \\
\hline 23. & Kfifan-Our Lady of Ramat & $\bullet$ & & & $\bullet$ & & \\
\hline 24. & Koubba-St. Savior & $\bullet$ & & & $\bullet$ & & \\
\hline 25 & $\begin{array}{l}\text { Mrah Chdid-Deir Chouah- } \\
\text { St. Sergius \& St. Bacchus }\end{array}$ & $\bullet$ & & & $\bullet$ & & \\
\hline $26 \alpha$ & $\begin{array}{l}\text { Rachkida-St. Korkis } \\
\text { (St. George)The first church }\end{array}$ & & & $\bullet$ & $\bullet$ & & \\
\hline $26 \beta$ & $\begin{array}{l}\text { Rachkida-St. Korkis } \\
\text { (St. George)The second } \\
\text { church }\end{array}$ & & $\bullet$ & & & $\bullet \mathbf{L}$ & \\
\hline 27. & Sghar-Archangel Michael & $\bullet$ & & & $\bullet$ & & \\
\hline 28. & $\begin{array}{l}\text { Sghar-St. Sophia } \\
\text { \& St. Stephen }\end{array}$ & & $\bullet \|$ & & & $\bullet$ & \\
\hline 29. & $\begin{array}{l}\text { Smar Jbeil- Our Lady } \\
\text { of the Help }\end{array}$ & $\bullet$ & & & $\bullet$ & & \\
\hline 30. & $\begin{array}{l}\text { Smar Jbeil-Sts Basilios } \\
\text { \& Nohra }\end{array}$ & & $\bullet \|$ & & & $\bullet$ & \\
\hline 31. & $\begin{array}{l}\text { Tannourine Fawqa(upper)- } \\
\text { St. Challita \& St. George }\end{array}$ & & $\bullet \| \square$ & & & $\bullet$ & \\
\hline $32 \alpha$ & $\begin{array}{l}\text { Tannourine Tahta(lower) - } \\
\text { Our Lady \& St. Anthony }\end{array}$ & $\bullet$ & & & $\bullet$ & & \\
\hline $32 \beta$ & $\begin{array}{l}\text { Tannourine Tahta(lower) - } \\
\text { Our Lady \& St. Anthony }\end{array}$ & $\bullet$ & & & $\bullet$ & & \\
\hline 33. & $\begin{array}{l}\text { Tannourine-Ain al Raha } \\
\text { Fawqa (upper)-St. George }\end{array}$ & $\bullet$ & & & $\bullet$ & & \\
\hline
\end{tabular}

$\square$ : Square Plan / /: Twin Church / L: Biconch Church

Table 3. Typology of the historic churches in Byblos.

\begin{tabular}{|c|c|c|c|c|c|c|c|}
\hline $\mathbf{N}^{\mathbf{0}}$ & Region - Name of the Church & $\begin{array}{l}\text { Single } \\
\text { Nave }\end{array}$ & $\begin{array}{l}\text { Double } \\
\text { Nave }\end{array}$ & $\begin{array}{l}\text { Triple } \\
\text { Nave }\end{array}$ & $\begin{array}{l}\text { Single } \\
\text { Apse }\end{array}$ & $\begin{array}{l}\text { Double } \\
\text { Apse }\end{array}$ & $\begin{array}{l}\text { Triple } \\
\text { Apse }\end{array}$ \\
\hline 1 & $\begin{array}{l}\text { Abadat - kfour - Saqiet el } \\
\text { Khayt-Bouwali valley- } \\
\text { St. Simon Stylites }\end{array}$ & caverı & s temple & & & & \\
\hline 2 & $\begin{array}{l}\text { Abadat-Our Lady } \\
\text { Wataya }\end{array}$ & $\bullet$ & & & $\bullet \equiv$ & & \\
\hline
\end{tabular}




\begin{tabular}{|l|l|l|l|l|l|l|l|}
\hline $\mathbf{N}^{\mathbf{0}}$ & $\begin{array}{l}\text { Region - Name of the } \\
\text { Church }\end{array}$ & $\begin{array}{l}\text { Single } \\
\text { Nave }\end{array}$ & $\begin{array}{l}\text { Double } \\
\text { Nave }\end{array}$ & $\begin{array}{l}\text { Triple } \\
\text { Nave }\end{array}$ & $\begin{array}{l}\text { Single } \\
\text { Apse }\end{array}$ & $\begin{array}{l}\text { Double } \\
\text { Apse }\end{array}$ & $\begin{array}{l}\text { Triple } \\
\text { Apse }\end{array}$ \\
\hline $\mathbf{3}$ & $\begin{array}{l}\text { Ain al Dilbi- Our Lady } \\
\text { Of al Midan }\end{array}$ & $\bullet$ & & & $\bullet \equiv$ & & \\
\hline 4 & $\begin{array}{l}\text { Ain Kfaa-St. Simon } \\
\text { \& St. Abdas }\end{array}$ & & $\bullet$ & & & $\bullet$ & \\
\hline $\mathbf{5}$ & $\begin{array}{l}\text { Amchit-Kfarsala-St. John } \\
\text { the Baptist }\end{array}$ & $\bullet$ & & & & $\bullet$ L & \\
\hline $\mathbf{6}$ & Amchit-Our Lady of Naya & $\bullet$ & & & $\bullet$ & & \\
\hline $\mathbf{7}$ & Amchit-St. Zakhia & $\bullet$ & & & $\bullet$ & & \\
\hline $\mathbf{8}$ & $\begin{array}{l}\text { Annaya-Kfarbaal-St. } \\
\text { Joachim and St. Anne }\end{array}$ & $\bullet$ & & & $\bullet \equiv$ & & \\
\hline $\mathbf{9}$ & Aqora al-St. Edna & $\bullet$ & & & $\bullet \equiv$ & & \\
\hline $\mathbf{1 0}$ & $\begin{array}{l}\text { Bahdidat - St. Nicholas } \\
\text { \& Our Lady of Bzez (breast) }\end{array}$ & $\bullet$ & & & $\bullet$ & & \\
\hline $\mathbf{1 0}$ & $\begin{array}{l}\text { Bahdidat - St. Nicholas } \\
\text { \& Our Lady of Bzez (breast) }\end{array}$ & $\bullet$ & & & $\bullet$ & & \\
\hline $\mathbf{1 1}$ & $\begin{array}{l}\text { Bahdidat-St. Theodoros } \\
\text { Stratilatis }\end{array}$ & $\bullet$ & & & $\bullet$ & & \\
\hline $\mathbf{1 2}$ & Bejji-Our Lady of al Mazraa & $\bullet$ & & & $\bullet$ & & \\
\hline $\mathbf{1 3}$ & Bekhaaz-St. George & $\bullet$ & & & $\bullet$ & & \\
\hline $\mathbf{1 4}$ & Bentael-St. Mammes & $\bullet$ & & & $\bullet$ & & \\
\hline $\mathbf{1 5}$ & Barbara al-St. John & $\bullet$ & & & $\bullet$ & & \\
\hline $\mathbf{1 6}$ & Barbara al-St. Sergius & $\bullet$ & & & $\bullet$ & & \\
\hline $\mathbf{1 7}$ & Blat al-Mdamit-St. Domitian & $\bullet$ & & & $\bullet$ & & \\
\hline $\mathbf{1 8}$ & Blat al-St. Elias & & & $\bullet$ & $\bullet \equiv$ & & \\
\hline $\mathbf{1 9}$ & Bshalli- St. George & $\bullet$ & & & $\bullet \equiv$ & & \\
\hline $\mathbf{2 0}$ & $\begin{array}{l}\text { Chamat-St Thecla } \\
\text { \& St. Stephen }\end{array}$ & & $\bullet \|$ & & & $\bullet$ & \\
\hline $\mathbf{2 1}$ & Chikhane-St. Simon Stylites & $\bullet$ & & & $\bullet$ & & \\
\hline $\mathbf{2 2}$ & Chikhane-St. Thecla & & & $\bullet$ & $\bullet$ & & \\
\hline $\mathbf{2 3}$ & Chmout-St. Phocas & $\bullet$ & & & $\bullet$ & & \\
\hline $\mathbf{2 4}$ & $\begin{array}{l}\text { Dmalsa-St. Nohra } \\
\text { \& St. Sophia }\end{array}$ & & $\bullet \|$ & & & $\bullet$ & \\
\hline $\mathbf{2 5}$ & Edde-St. Elias & $\bullet$ & & & $\bullet$ & & \\
\hline $\mathbf{2 6}$ & Edde-St. George & $\bullet$ & & & $\bullet$ & & \\
\hline $\mathbf{2 7}$ & Edde-Pr. Lichaa & $\bullet$ & & & $\bullet$ & & \\
\hline $\mathbf{2 8}$ & $\begin{array}{l}\text { Edde-St. Theodoros \& St. } \\
\text { John }\end{array}$ & & $\bullet$ & & & $\bullet$ & \\
\hline $\mathbf{2 9}$ & $\begin{array}{l}\text { Edde-the Archangels } \\
\text { Michael \& Gabriel }\end{array}$ & & $\bullet$ & & & $\bullet$ & \\
\hline $\mathbf{3 0}$ & $\begin{array}{l}\text { Fdar al Tahta-Beshtlide-Our } \\
\text { Lady of the Help }\end{array}$ & $\bullet$ & & & $\bullet$ & & \\
\hline $\mathbf{3 1}$ & Fidar al-St. Zakhia & $\bullet$ & & & $\bullet$ & & \\
\hline $\mathbf{3 2}$ & Gharzouz-40 Martyrs & $\bullet$ & & & $\bullet$ & & \\
\hline 33 & Habil-Our Lady of Habil & $\bullet$ & & & & $\bullet$ L & \\
\hline
\end{tabular}




\begin{tabular}{|c|c|c|c|c|c|c|c|}
\hline $\mathbf{N}^{\mathbf{o}}$ & $\begin{array}{l}\text { Region - Name of the } \\
\text { Church }\end{array}$ & $\begin{array}{l}\text { Single } \\
\text { Nave }\end{array}$ & $\begin{array}{l}\text { Double } \\
\text { Nave }\end{array}$ & $\begin{array}{l}\text { Triple } \\
\text { Nave }\end{array}$ & $\begin{array}{l}\text { Single } \\
\text { Apse }\end{array}$ & $\begin{array}{l}\text { Double } \\
\text { Apse }\end{array}$ & $\begin{array}{l}\text { Triple } \\
\text { Apse }\end{array}$ \\
\hline 34 & Habil-St. George & $\bullet$ & & & $\bullet \equiv$ & & \\
\hline 35 & $\begin{array}{l}\text { Habil-St. Sergius } \\
\text { and St.Bacchus }\end{array}$ & $\bullet$ & & & $\bullet$ & & \\
\hline 36 & Hakel-Our Lady of Hakel & $\bullet$ & & & $\bullet \equiv$ & & \\
\hline 37 & $\begin{array}{l}\text { Hisrail-Kawr al Hawa- } \\
\text { St. Theodoros }\end{array}$ & $\bullet$ & & & • & & \\
\hline 38 & $\begin{array}{ll}\text { Jbeil } & \text { Town-Mehrin-St. } \\
\text { Marina } & \end{array}$ & $\bullet$ & & & $\bullet$ & & \\
\hline 39 & $\begin{array}{l}\text { Jbeil Town-Our Lady of } \\
\text { Najat }\end{array}$ & $\bullet$ & & & $\bullet$ & & \\
\hline 40 & $\begin{array}{l}\text { Jbeil Town- Our Lady } \\
\text { of the Gate }\end{array}$ & $\bullet$ & & & $\bullet$ & & \\
\hline 41 & Jbeil Town-Poor Mother & $\bullet$ & & & $\bullet \equiv$ & & \\
\hline 42 & Jbeil Town-St. John Marcus & & & $\bullet$ & & & $\bullet$ \\
\hline 43 & Jbeil Town-St. Nohra & $\bullet$ & & & $\bullet$ & & \\
\hline 44 & $\begin{array}{|lll|}\text { Jbeil } & \text { Town-St. } & \text { Simon } \\
\text { Stylites } & & \\
\end{array}$ & $\bullet \square$ & & & $\bullet$ & & \\
\hline 45 & $\begin{array}{l}\text { Jbeil Town-Zgheib - } \\
\text { St. Aquilina }\end{array}$ & $\bullet$ & & & • & & \\
\hline 46 & Kafer al-St. George & $\bullet$ & & & $\bullet$ & & \\
\hline 47 & $\begin{array}{lll}\text { Maad-St. } & \text { Charbel the } \\
\text { Martyr }\end{array}$ & & & $\bullet$ & & & $\bullet$ \\
\hline 48 & Mastita-St. Sava & $\bullet$ & & & $\bullet \equiv$ & & \\
\hline 49 & $\begin{array}{l}\text { Mayfouk-al Qattara-St. } \\
\text { Moura }\end{array}$ & $\bullet$ & & & $\bullet \equiv$ & & \\
\hline 50 & $\begin{array}{l}\text { Mayfouk-Bernassa-St. } \\
\text { George }\end{array}$ & $\bullet$ & & & • & & \\
\hline 51 & Mayfouk-Bernassa-St. Sava & $\bullet$ & & & $\bullet$ & & \\
\hline 52 & Mayfouk-Our Lady of Elige & & & $\bullet \square$ & & & $\bullet$ \\
\hline 53 & Mayfouk-St. John & $\bullet$ & & & $\bullet \equiv$ & & \\
\hline 54 & Michhlan-St. Edna & $\bullet$ & & & $\bullet$ & & \\
\hline 55 & Moncef al-St. George & $\bullet$ & & & $\bullet$ & & \\
\hline 56 & Moncef al-St. Mammes & $\bullet$ & & & $\bullet$ & & \\
\hline 57 & $\begin{array}{l}\text { Qassuba Hill- Our Lady } \\
\text { of Qassuba }\end{array}$ & $\bullet$ & & & $\bullet$ & & \\
\hline 58 & Rihane al-St. Theodoros & $\bullet$ & & & $\bullet$ & & \\
\hline 59 & Tartij-St. George & $\bullet$ & & & $\bullet$ & & \\
\hline
\end{tabular}

$\square$ : Square Plan / I: Twin Church / L: Biconch Church / $\equiv:$ Flat Apse

As a consequence, we can conclude these following observations:

In Koura

About naves:

The single-naved churches are twenty eight 
- $\quad$ The double-naved churches are four

- $\quad$ The triple-naved churches are four

About apses:

- $\quad$ There is only one cavernous temple

- The single-apsed churches are thirty

- $\quad$ The double-apsed churches are five

- $\quad$ There is only one triple-apsed church

It is observed that:

There is only one cavernous temple

- $\quad$ The triple-apsed church is triple-naved

- $\quad$ The most of double-apsed churches are double-naved

- $\quad$ There is one square single-naved church

- $\quad$ There are two square triple-naved churches

In Batroun:

About naves:

About apses:

- The double-apsed churches are nine

- $\quad$ There is one double-apsed cavernous temple

(The two apses are built inside the cave)

- $\quad$ There is one cavernous temple without apses

- $\quad$ There isn't any triple-apsed church

It is observed that:

- $\quad$ Four double-apsed churches are in Hardine

- $\quad$ The most of double-apsed churches are double-naved

- $\quad$ There are two square single-naved churches

- $\quad$ There is one square double-naved church

In Byblos:

About naves:

About apses: The single-apsed churches are forty nine

- $\quad$ The double-naved churches are seven

- The triple-apsed churches are three

- $\quad$ There is only one cavernous temple

It is observed that:

The single-naved churches are forty nine

- $\quad$ The double-naved churches are five

- $\quad$ The triple-naved churches are five

- $\quad$ There is only one cavernous temple

- $\quad$ The triple-apsed churches are triple-naved

- $\quad$ The most of double-apsed churches are double-naved

- $\quad$ There are three square single-naved churches 
- $\quad$ There is only one square triple-naved church

\section{CONCLUSION}

As a result of our study, we consider that the Christianity was widespread in Lebanon; this led to the existence of a large number of churches with distinctive typology and played an important role in the history of Christian architecture in our area, which deserves to be analyzed.

Most local churches were financed by the inhabitants and were made by local craftsmen, who created an ecclesiastical architecture closely tied to their place, but the dire economic situation prevented the implementation of large temples. Even if most local temples are poor, they are important because they give us the opportunity to study the early architecture of Christianity in our region concerning their function and history. This rich ecclesiastical architecture makes us proud because we are the heirs of the great ancestors, who left us a precious heritage that is a treasure of culture, art, history and faith. That is why it is important to study them, hoping that the competent authorities will take action to repair the damages of these historic churches.

\section{ACKNOWLEDGMENT}

Special thanks to Professor Prepis Alkiviadis, my Ph.D. Supervisor at Democritus University of Thrace in Greece, for his valuable help. I am grateful to the University of Balamand in Lebanon for granting this article with the necessary data.

\section{REFERENCES}

Website https://home.balamand.edu.lb/ARPOA. Religious Architecture of the Orthodox Patriarchate of Antioch. University Of Balamand, Lebanon.

Kurkjian, Houry. 2003. The Double Churches from Jbeil to Akkar. Lebanese University. Nordiguian, Levon and Voisin, Jean-Claude. 1999. Castles and Churches of the Middle Ages in Lebanon, editions land of Lebanon.

Saber, Anwar. 2003. The Virgin Mary in Lebanon, Volume IV, Al Koura. Notre Dame University, Lebanon.

Saber, Anwar. 2005. The Virgin Mary in Lebanon, Volume V, Al Batroun. Notre Dame University, Lebanon.

El Khoury, A. Christian. 2008. The Virgin Mary in Lebanon, Volume VII, Jbeil. Notre Dame University, Lebanon.

Kahwaji-Janho, Hany. 2018. The Double Churches of Lebanon Forms, Types and Evolutions. Holy Spirit University of Kaslik, Lebanon.

Nordiguian, Levon. 2018. Medieval Chapels of Kour El Aarabi, Chronos No 38, pp. 171190. University Of Balamand, Lebanon.

Cruikshank-Dodd (Husband's last name), Erica. 2014. On Double Churches in the Lebanon, Word of the Orient 39, pp. 313-337, American University of Beirut, Lebanon.

Plans were downloaded from https://home.balamand.edu.lb/ARPOA, https://www.google.com and were drawn by Raffi Gergian, A. Salem, George Michell, Rwiya Majzoub, Camille Enlart and the author. 